\title{
Continuity and Change in Parsons' Understanding of Rationality
}

Raf Vanderstraeten

The chapter that Talcott Parsons prepared for the Parsons-Schumpeter Seminar on 4 Rationality in the Social Sciences consists of not more than five and a half pages. It 5 also gives the impression of being a hastily drafted, somewhat incoherent text, 6 which mainly reiterates arguments presented in the chapters on Vilfredo Pareto in 7 The Structure of Social Action (Parsons 1937, 1968a). In the period around 1940, 8 when the Seminar on Rationality took place at Harvard University, Parsons seemed 9 to have lost much of his original interest in discussing, revisiting, and 10 complementing economic approaches to the nature of rationality and the rational 11 pursuit of self-interest.

In the autobiographical essay "On Building Social System Theory: A Personal 13 History," Parsons shed some light on his own intellectual trajectory and academic 14 career-including the period after the completion of The Structure of Social Action. 15 In the late 1920s, he had entered Harvard University through the Economics 16 Department. But in the course of the following decade, he transferred, both intel- 17 lectually and institutionally, from economics to sociology. Relatively late, in 1939, 18 he received tenure in Harvard's Department of Sociology. "In spite of the friend- 19 liness of [the economists] Taussig, Gay, and Schumpeter, I am quite sure I could not 20 have counted on a future in economics at Harvard. But basically I did not want to do 21 so... Though I wanted to keep my contact with economic theory, and in fact have 22 done so in various ways, I saw clearly that I did not want to be primarily an 23 economist, any more than Weber turned out to be" (Parsons 1070 1977: 32). 24

Parsons, however, also explicitly referred to the Seminar ationality in the 25 Social Sciences:

"There was one interesting episode which might, at a relatively late time, have turned me at $\quad 27$ last farther in the direction of economics. After my formal transfer to sociology, 28

R. Vanderstraeten $(\square)$

Center for Social Theory, Ghent University, Ghent, Belgium

e-mail: Raf.Vanderstraeten@UGent.be 
Schumpeter organized a small discussion group with younger people, mostly graduate students, on problems of the nature of rationality. After a few meetings he proposed to me that the group should aim at producing a volume, of which he and I should be at least coeditors, if not coauthors. Though not specifically rejecting the proposal, at least immediately, I remembered having reacted rather coolly, and in fact I let it die. I am not wholly clear about my motives, but I think they had to do with the feeling that I needed a relatively complete formal break with economics." (1970, 1977: 32-33)

Despite his career change, Parsons" decision to "let it die" is a remarkable one. Parsons was some 20 years younger than Schumpeter. While he was in the late 1930s in an early stage of his career, Schumpeter was a well-established economist and an ex-minister of finance, who had also expressed his willingness to support Parsons' career within the Harvard setting. Parsons described Schumpeter's proposal as "flattering . . . for a young and still insecure scholar" (1970, 1977: 35). ${ }^{1}$ Moreover, problems of rationality remained central to Parsons' sociological theory throughout most of his career. Some commentators have even argued that Parsons' sociological project can be defined as an ongoing reflection on the meaning and limits of rationality (see Stichweh 1980; Hein 2009). It therefore seems relevant to pay attention to transitions in Parsons' understanding of rationality. Next to Parsons' formal transfer from the Economics to the Sociology Department at Harvard, such transitions might also have affected his collaboration with Schumpeter.

I will now proceed to highlight some lines of continuity and change in Parsons' understanding of rationality in order to shed light on his decision to "let it die." I will, more particularly, point to a basic transition in Parsons' understanding of rationality in society-from an individualized, actor-oriented conception of rationality to one which deals with rationality as value pattern at the level of social systems. The first indications of this transition can already be observed in work on the professions, on which Parsons embarked shortly after the publication of The Structure of Social Action (e.g., Parsons 1939, 1954). But The American University (Parsons and Platt 1973), which is the last monograph that Parsons saw into print, also contains elaborate discussions of the problem of rationality. Perhaps Parsons' chapter on cognitive rationality in that monograph might be read as his full chapter for the Seminar on Rationality, which took place more than three decades earlier.

On the following pages, I argue that the tensions which accompanied the transitions in Parsons' understanding of rationality account for Parsons' ambivalent attitude toward the publication project with Schumpeter and others in the period around 1940. By focusing on the shifting architecture of his theoretical account of rationality and modern society, I intend to discuss this transition-or this process of

\footnotetext{
${ }^{1}$ Schumpeter had been one of the supportive reviewers of the manuscript of The Structure of Social Action for the Committee on Research in the Social Sciences (which had financed Parsons' research). At the same time, however, Schumpeter was in this report one of the first to comment on Parsons' cumbersome prose: "The author has in fact so deeply penetrated into the German thicket as to lose in some place the faculty of writing clearly in English about it, and some turns of phrase become more fully understandable only if translated into German" (cited by Swedberg in Schumpeter 1991: 97). For more background information on the relation between Schumpeter and Parsons, see also Allen (1991: 98) and Swedberg (2015).
} 
"continuity and change," as Parsons typically liked to put it -in somewhat more 66 detail. Although facing the risk of oversimplification, I hope to show some lines of 67 transition in the large body of scholarly work that Parsons produced in the course of 68 about half a century.

\section{The Structure of Action}

In his early writings, Parsons advocated using an "analytical realism" to build a 71 coherent theoretical or conceptual framework for sociology. In The Structure of 72 Social Action, he stated that this theoretical framework had to consist of a 73 limited number of important concepts that "adequately 'grasp' aspects of the 74 objective external world... These concepts do correspond, not to concrete 75 phenomena, but to elements in them which are analytically separable from 76 other elements" (1937, 1968a: 730). Much like Max Weber, Parsons argued 77 that theory had to involve the development of concepts that grasp the systemic 78 features of the universe without being overwhelmed by empirical details. Social 79 theory, more particularly, had to reflect significant features in the organization 80 of social phenomena. For Parsons, the "voluntaristic theory of action," presented 81 in a number of early essays and in The Structure of Social Action, constituted an 82 important step in this direction.

Critically building on the writings of classical economists, such as Marshall and 84 Pareto, Parsons took the "problem of the rationality of action" as starting point for 85 his reflections on the nature of modern capitalism. In The Structure of Social Action, 86 he maintained that there was "obviously a very solid common-sense foundation for 87 attributing a large importance to rationality in action. We are all engaged in 88 multifarious practical activities where a great deal depends on the 'right' selection 89 of appropriate means to our ends, and where the selection, within the limits of 90 knowledge current at the time and place, is based on a sound empirical 91 knowledge... [T] here can be no question of the pervasiveness of the rational case 92 in all systems of human action" (1937, 1968a: 57).

Parsons not only linked rationality with the use of empirically sound knowledge. 94 $\mathrm{He}$ also connected the concept of rationality with what economists called the 95 process of want satisfaction. The model of the individual homo economicus, who 96 strived to satisfy his wants to obtain his goals in the most efficient way, constituted 97 the paradigmatic example of rationality: "the process of want satisfaction is itself 98 the most general and obvious meaning of rationality of action" (1937, 1968a: 133). 99 In many ways, the analyses Parsons presented in his early work departed from such 100 an economic, utilitarian conception of rationality at the individual level ("Crusoe 101 economics"). So also did Parsons' emphasis on the "unit act" and its basic constit- 102 uents in The Structure of Social Action. The point of departure of Parsons' 103 
"analytical realism" was a critique of the writings of classical economists. He did not reject the basic assumptions of this approach but aimed to modify and complement them. ${ }^{2}$

In a discussion of Pareto's logical norm of rational action, for example, Parsons put emphasis on the "theoretical significance" of Pareto's approach. Pareto had been able to "define rigorously one of the principal types of norm governing the means-end relationship" (1937, 1968a: 191). At the same time, however, he also put stress on the limitations of Pareto's approach. He proposed a "slightly different use" of the norm. In this light, he defined the aim and program of The Structure of Social Action in the following terms: "The most important questions for further inquiry will be, what is the rest of the structure of acts and systems of action of which a norm of this character can form a part and at what point does the 'logical' norm fit into this structure?" (1937, 1968a: 191). Stated somewhat differently, Parsons' aim was to situate the concept of rationality in action within a broader framework, within which the nonrational conditions and components of action could also be taken into account.

To arrive at this framework, Parsons proposed several modifications to the existing conception of rationality. Already in his early essays, in which the relation between economics and sociology was an explicit topic of discussion, he stated that rationality, defined in terms of economizing or exploiting means in order to achieve ends, is not "a descriptive generalization ... [but] a norm of rational action" (1934: 520, orig. emphasis). Economic "laws" were very different from "Newtonian or Einsteinian formulae." The empirical relevance of rationality "rests on the circumstance that men do in fact try (nor merely 'tend') ... to 'exploit' the conditions of their lives rationally in order to satisfy their wants. This idea of a norm which men can be conceived as striving to attain by effort is something entirely foreign to the 'positive' physical sciences" (1934: 520, orig. emphases). For Parsons, a sociologically adequate theory of action thus had to be based on a "voluntaristic" foundation. "Effort," as he put it in The Structure of Social Action, "is a name for the relating factor between the normative and the conditional elements of action. It is necessitated by the fact that norms do not realize themselves automatically but only through action, so far as they are realized at all" (1937, 1968a: 719).

Parsons tried to develop this "voluntaristic" theory of action in two different directions. On the one hand, he aimed to include the nonrational components or conditions of action. A theory of action not only had to account for rational action, for the rational pursuit of self-interest. He also looked for ways to distinguish this

\footnotetext{
${ }^{2}$ In an article on utilitarianism, written for the International Encyclopedia of the Social Sciences, Parsons later also wrote: "The primary focus of utilitarianism was on the process of action designed to satisfy given wants of individuals - that is, on goal-attainment, or want-satisfaction, whichever way it was put. The process was understood to be one of choosing means that would effectively gain the end. Since this conception was inherently 'teleological', ... it required some normative reference beyond the more desirability of being satisfied. This was the origin of the famous concept of rationality in the restricted sense of choosing those means and concrete behaviors that are 'best adapted' to attainment of the end" (1968b: 229).
} 
form of action from other forms of irrational or nonrational action. For the indi- 140 vidual, action could also be symbolically meaningful, as in the case of religious 141 rituals in which the means are symbolically but not rationally related to the religious 142 goals (see also Parsons 1939, 2010). At the end of his short contribution to the 143 Seminar on Rationality, Parsons equally pointed to the cultural determinants of 144 rationality in the system of action: "there is a great deal of evidence that rationality 145 is only one of the modes in which systems of action are integrated. The attempt to fit 146 action in such fields as religion, magic, art and perhaps various others entirely into 147 the conceptual scheme of rationality, results in severe distortion of the facts and 148 gross misinterpretations" (p. 40 of this volume). Next to the norm of rationality, 149 other social norms could also motivate individuals to act meaningfully in particular 150 situations or circumstances.

On the other hand, he questioned the instrumentalist assumption underlying 152 economic accounts of rationality. For Parsons, existing economic theories exclu- 153 sively discussed rationality in terms of the relation between means and ends. These 154 theories did not include the ends or goals in the interest of which such "instrumental 155 rationality" was brought to bear within their frame of reference. Parsons also spoke 156 of the assumption of the "randomness of ends." In his autobiographical essay "On 157 Building Social System Theory: A Personal History," he later wrote: "The utilitar- 158 ians, and still for the most part, economists, treated consumption 'wants' as given, 159 that is, as not constituting the locus of intellectual problems for their purposes" 160 (1970, 1977: 72). For Parsons, the status of these ends also needed to be specified 161 theoretically. Ends often were embedded within systems of ends-and therefore 162 anything but random or irrational. The implication was that "the "universe of 163 values' is not devoid of rational organization and that decisions of 'commitment 164 to' values ... have a rational component which is independent of instrumentality" 165 (1970, 1977: 73).

To elucidate his point of view, Parsons distinguished between three realms: 167 ultimate means, ultimate ends, and an intermediate chain of means-end relations in 168 which ends are always also means to achieve other ends. He claimed, for example, 169 that most actions are "both means and ends-means to more ultimate ends, but also 170 ends of the actions leading up to them. In this intermediate sector of the means-end 171 chain will belong all elements of action other than the ultimate ends, except the 172 'ultimate means' at the other end of the chain, the fundamental 'positivistic' factors 173 of 'environment' and 'human nature"” (1934: 529). In "The Place of Ultimate 174 Values in Sociological Theory," he also stated that action in "pursuit of immediate 175 non-ultimate ends" was subjected "to normative rules which regulate that action in 176 conformity with the common ultimate value-system of the community" (1935: 177 299). In this sense, Parsons extended the reach of rationality. He argued that 178 rationality could not only pertain to means-ends relationships; rational action not 179 just took place in an environment of "random ends." The normative organization of 180 the chain of "unit acts," of intermediate means-ends relationships, had itself to be 181 addressed within the action theoretical framework. 182

Parsons' rejection of the utilitarian assumption of the randomness of ends thus 183 led him to focus on the normative organization of action. In his view, actors 184 
typically relied on an integrated system of ends. He also believed that such integrated system of ends had to exist at the social level. Without coherent system of ends, no social order could exist. Without a broad range of social institutions that could specify and concretize the ultimate values and thereby provide structure to social action, no conformity with the ultimate ends of the total society could be ensured. Hence, also Parsons developed a concern with the institutionalization of ultimate ends or values, with the ways in which these values could circumscribe systems of social action. From this point of view, he maintained that sociology "would become the science of the rôle of ultimate common ends and the attitudes associated with and underlying them, considered in their various modes of expression in human social life" (1934: 529). Like Durkheim, Parsons believed that ultimate common ends or values "constrained" human action. By focusing upon the relation between social institutions and common values, Parsons believed that sociology would be able to legitimize itself as one of the behavioral sciences.

While Parsons sketched the outlines of what he thought to be sociology's mission in his early work, it has also often been remarked that he was hardly able to provide detailed hints of how this mission was to be carried out (e.g., Turner 1988). Near the end of The Structure of Social Action, Parsons also recognized that "any atomistic system that deals only with properties identifiable in the unit act ...will of necessity fail to treat these latter elements adequately and be indeterminate as applied to complex systems" (1937: 738-739). It is evident that his focus on the atomistic unit act ensued from his orientation toward individual action - and the ways it had been conceived in the economic, utilitarian tradition. For our purposes, it is also instructive to point to some underlying ambiguities in the voluntaristic theory of action, which might account for its limitations.

It is particularly instructive to pay attention to the distinction that Parsons drew between two types of norms organizing and controlling human action: efficiency norms and institutionalized moral norms. In "The Place of Ultimate Values in Sociological Theory," he used the example of religious rituals to contrast "two types of authority in norms - efficiency and moral obligation... Our attitude to [religious] ritual hence tends to be that kind of respect which we give to moral rules rather than the utilitarian attitude which predominates in attempts to realize a norm of efficiency" (1935: 303-304). Elsewhere, he discussed in a similar way the modes in which economic institutions could exercise control in order to "govern the whole complex of economic activities of a society. This control operates essentially in the form of a set of normative rules, obligatory on the participants (quite different from norms of 'efficiency') and governing the whole complex of economic activities of a society" (1934: 533). As these examples show, Parsons' concern was with the institutionalized moral norms or obligations, not with "the utilitarian attitude" or the "norm of efficiency." Despite his focus on voluntarism and normative constraints, he tended to treat rationality as a "natural" phenomenon that did not need sociological explanation.

Another illustration can be found in Parsons' discussion of "rationalization." The concept of rationalization is introduced at the end of The Structure of Social Action. Parsons proposed, more particularly, an "analytical law" of "increasing 
rationality": "a process of action can proceed only in the direction of increase in the 230 value of the property rationality" (1937, 1968a: 751). This law was compared to the 231 second law of thermodynamics (entropy) —with the purpose of highlighting the 232 irreversibility or directionality of rationalization processes. "Rationality occupies a 233 logical position in respect to action systems analogous to that of entropy in physical 234 systems. . . Effort energy is, in the processes of action, converted into realization of 235 ends, or conformity with norms. Rationality is one, at least, of the properties in 236 terms of which the extent of this change is to be measured for any given system at 237 any given point in the process of change" (1937, 1968a: 752, orig. emphasis). 238 Rationalization thus referred to the realization or implementation of ultimate ends 239 or values. While Parsons stressed that ultimate ends could vary, which different 240 "value spheres" (Weber) existed, he again adhered to a universalist conception of 241 rationality. While he stressed cultural relativity at the level of the ultimate ends, he 242 also believed that some kind of "value pressure," oriented toward the rational and 243 efficient implementation of these values, was intrinsic to human action systems. 244

Again, we may assume that these tensions and ambiguities are a result of 245 Parsons' starting point. Parsons departed from an instrumental and individualized 246 conception of rationality. He built on the utilitarian assumption that individual 247 action was rational in as far as the available means were used in the most efficient 248 way for attaining the goals. In The Structure of Social Action, he wrote: "the 249 procedure throughout has been one of cautious advance from well-known and 250 clearly formulable 'islands' of theoretical knowledge-above all the conception 251 of science in relation to the rationality of action-bit by bit into the unknown" 252 (1937, 1968a: 627). But his starting point and cumulative "procedure" led him to 253 accept a natural inclination to act rationally or efficiently. Both stood in the way of a 254 sociological understanding of rationality. He did not yet offer an account of the 255 problem of social rationality. In his early work, rationality seemed exempted from 256 social determination. Parsons rather seemed inclined to define sociology as the 257 science of the nonrational.

\section{The Professions}

After the completion of The Structure of Social Action, Parsons embarked on a large 260 and ultimately lifelong study of the professions. This project is closely built upon 261 the analyses presented in The Structure of Social Action. His interest remained in 262 the development of a theoretical account of the conditions of modern capitalism. He 263 again questioned the reach and adequacy of existing utilitarian theories, in which 264 the modern world is paradigmatically understood as a more or less integrated 265 collective of individual actors, who are rationally pursuing their self-interests. 266

The starting point of Parsons' writings on the professions was the question 267 whether professional activity could be adequately understood as a special form of 268 economic activity as conceived in the utilitarian tradition. He particularly 269 questioned whether the relationship between professionals and clients could be 270 
understood as a special form of economic relationship. For Parsons, professional activity could not only be driven by self-interest, because clients could not be treated as means toward ends. But he also believed that professional activity was a (if not the) form of rational activity. As no other type of work, professional work depended on the application of scientifically sound knowledge (e.g., Parsons 1937, 1939, 1954). The extensive scientific and humanistic training which professionals had to undergo at the university level made it in his view clear that professions had to be dealt with as applied sciences, as distinctly rational institutions.

From this point of view, Parsons again touched upon the meaning of the concept of rationality. One of the main assumptions of the utilitarian paradigm, viz., that the rationality of action follows from the pursuit of self-interest, made it difficult to understand the rationality of professional work. For Parsons, the question was how the orientation to one's own interests could be combined with the "disinterestedness" of the professions. In his early sociology of the professions, Parsons thus already introduced one of the pattern variables he would later develop more systematically, viz., self- vs. disinterestedness or self- vs. collectivity-orientation (e.g., Parsons and Shils 1951: 90-91).

In these writings, one can also observe how his understanding of rationality started to shift. For Parsons, rationality no longer was a kind of "natural" implication of the pursuit of self-interest. He put more emphasis on the institutional and normative framework within which professional activities had to be carried out. He defined rationality as a value pattern that was characteristic of modern society. In different contexts, this overarching value pattern could be specified in different ways. Depending on the situation, rational orientations could call for "self-interest" or "disinterestedness." Seen in this light, one may also understand why Parsons was hesitant to collaborate with economists, such as Schumpeter, in order to develop another, sociological conception of rationality.

In the essay "The Professions and Social Structure," which was originally published in 1939, Parsons explicitly questioned the naturalness or universality of rationality. He described the context within which the business man, the foreman of labor, and the professional man had to define "the "best' thing to do" or to find "the most 'efficient' way of carrying on his function" in the following way: "rationality in this sense is institutional, a part of a normative pattern: it is not a mode of orientation which is simply 'natural' to men. On the contrary comparative study indicates that the present degree of valuation of rationality as opposed to traditionalism is rather 'unnatural' in the sense that it is a highly exceptional state. The fact is that we are under continual and subtle social pressure to be rationally critical, particularly of ways and means" (1939, 1954: 37). The shift in meaning of the concept of rationality is evident. Parsons did not hold onto the universality of rationality but instead drew attention to what he considered to be characteristic of modern, Western rationality.

It might be added that Parsons afterward also started to explore microsociological phenomena in his sociology of the professions. Best known perhaps are Parsons' analyses of the "sick role," of the institutionalization of the social role of being sick, and of the socialization of individuals into this role. His concern with 
psychosomatic problems, and eventually those of mental illness, led him to discuss 316 the accessibility of non- and irrational forces to rational understanding. It also led 317 him to consider the compatibility between social rationality and individual 318 nonrationality (or irrationality). In this sense, his micro-sociological analyses of 319 professional activities led him to distinguish more systematically between different 320 levels or dimensions. His understanding of rationality clearly started to shift: from 321 an emphasis on individual rationality to one on the social system and its major 322 institutions. As he later would put it, next to the distinction and relation between the 323 social and the cultural system, he now also started to consider the distinction and 324 relation between the social and the personality system (e.g., Parsons 1951: 325 428-479, 1968c, 1969; Parsons and Platt 1973: 225-266). 326

In the period around 1940, when the Seminar on Rationality took place, the 327 problem of rationality was not yet formulated in these terms. Only after the 328 introduction of the AGIL scheme (see below), these distinctions were more sys- 329 tematically addressed. Parsons' early sociology of the professions was driven by a 330 scholarly interest in the conditions of modern capitalism and modern society. 331 Parsons looked for structural anomalies, i.e., structural phenomena that did not fit 332 into the dominant utilitarian paradigm. His understanding of rationality started to 333 shift as a consequence of his attempts to deal with the many complexities of 334 professional work. In his autobiographical essay "On Building Social System 335 Theory," he referred to this "shifting ground" in the following way: 336

"I used the economic paradigm of the 'rational pursuit of self-interest' as the major point of $\quad 337$ reference, but in this case negatively, to throw light on the differences between the classical 338 economic model of market orientation and the professional case with which I was 339 concerned... The most important theoretical implications concerned the problem of the 340 nature of rationality, the very question with which I had been involved, not only in my own 341 work, but also in my work with Schumpeter. What opened up was a distinction, not only 342 between economic and noneconomic aspects of rationality, but also, within the latter 343 category, between two different modes or directions of considering the rationality problem. $\quad 344$ The first concerned a very old problem, even for me, namely the relation between rational 345 (mainly scientific) knowledge and action in the sense of 'application'... The concern with 346 psychosomatic problems, and eventually those of mental illness, noted above, raised a 347 different set of questions... I suspect that concern with this complex of problems had a 348 good deal to do with my coolness toward Schumpeter's overture, flattering as that was for a $\quad 349$ young and still insecure scholar." (1970, 1977: 34-35, orig. emphasis; see also Parsons 350 1973, 2006: 8-14)

\section{Multiple Rationalities}

As we have seen, Parsons' half-hearted attempt to support the book project with 353 Schumpeter concealed underlying transitions in his approach to the rationality 354 problem. In the decades after the publication of The Structure of Social Action, 355 however, Parsons did not lose sight of this problem. Quite to the contrary, it 356 reappeared repeatedly in his writings. After the development of the AGIL scheme, 357 the first version of which was presented in the Working Papers in the Theory of 358 
Action (Parsons et al. 1953: 180-269), Parsons also started to address the problem of rationality through the construction of analytical schemes or models satisfying the AGIL requirements. ${ }^{3}$

In Economy and Society: A Study in the Integration of Economic and Social Theory, published in 1956 and coauthored by Neil J. Smelser, Parsons returned to the relation between sociology and economic theory (see also Smelser 1981). It should therefore not come as a surprise that Parsons also returned to the problem of rationality and rationalization. In Economy and Society, he particularly highlighted the relationship with the adaptive requirements of social systems: "we would like to reformulate the process of rationalization as the tendency of social systems to develop progressively higher levels of structural differentiation under the pressure of adaptive exigencies. Adaptive exigencies are not ... given only in the external situation, but involve the relation between the system and the situation. One aspect of this adaptive relation in every social system is a certain pressure to actualize the value system which is institutionalized in the system" (Parsons and Smelser 1956: 292, orig. emphasis). For Parsons, processes of rationalization thus now referred to processes of adaptation of social systems to the environment, which were elicited by cultural pressures ensuing from the value system of these social systems. Rationalization also referred to subsequent processes of structural differentiation, which facilitated the implementation of these cultural value systems.

Referring to Weber, Parsons also discussed the existence of "a plurality of possible value systems." Parsons and Smelser wrote: "Given tension between system and situation, ... economic production itself is a mechanism which helps to meet the adaptive exigencies of the system. This is the basis on which we have treated the economy as differentiated relative to the society's adaptive function. Mobilization of societal resources for adaptive functions, however, occurs on more than one level" (1956: 292). Structural differentiation thus allowed for the genesis of different rationalities. These rationalities were now seen as value patterns of differentiated subsystems, which defined "ideal types of action" (Weber). The form of "economic rationality," which dominated in the economic subsystem, constituted a straightforward expression of this societal rationality.

In Economy and Society, it is argued that "in the American case ... there is good reason to believe that economic functions are ranked highest" (1956: 176). But Parsons and Smelser did not specify why this adaptive function had gained primacy within the value system of "the total society." Neither did they address the question of the coherence of the plurality of systemic rationalities nor value systems and thus of value integration in Western and especially American society. In later works, however, Parsons addressed several aspects of these questions. In a range of publications, he described the fundamental patterns of orientation in modern

\footnotetext{
${ }^{3}$ As is probably well known, AGIL is an acronym composed of the initials of what Parsons claimed were the four analytic dimensions of any system of action: adaptation, goal attainment, integration, and latent pattern maintenance. For an instructive history of the elaboration of this scheme, see Sciortino (2015).
} 
Western society in terms of "instrumental activism" or "worldly instrumental 398 activism" (e.g., Parsons 1973, 1991, 2007: 144-147). In this characterization, 399 instrumental indicates that human action does not find its ultimate aim in itself 400 but is treated as instrumental to some interest or task imposed from outside its own 401 sphere of interest. In modern society, Parsons maintained, the emphasis on tran- 402 scendental religious goals has been replaced by a strong emphasis on individuals as 403 final reference point (hence worldly instrumental activism). Accordingly, modern 404 society is seen to exist for the benefit of independent individuals. It tends to be 405 judged in terms of its effectiveness in satisfying the independently given wants of 406 individuals. By contrast, the activistic component refers to the system/environment 407 relations of society and its subsystems and points to the formation of value 408 preferences that stimulate social systems to engage in an internal transformation 409 of, and control over, objects in their environment. Modern society is not concerned 410 with adaptation to the world but with adaptation of the world to society's needs. It is 411 concerned with mastery or control over the world (see also Weber 1920, 1988: 412 17-206).

In short, Parsons introduced a multidimensional concept of rationality in the 414 1950s. But he also believed in the existence of an overarching value system that 415 could guide and control the different rationalities. The value system of instrumental 416 activism gave preference to the different adaptive functions, to the adaptive 417 upgrading of action, while "value generalization" defined the relation between 418 different rationalities. These rationalities ensued from specifications of the same 419 overall value system. Against this background, Parsons' emphasis also gradually 420 shifted from the economy as the adaptive subsystem of the social system to 421 education and the rationality system as the adaptive subsystem of the fiduciary 422 system (see also Luhmann 1968, 1973: 14-17; Baum 1976).

\section{Cognitive Rationality}

In his late work, Parsons argued that the value pattern of "instrumental activism" 425 found its most clear-cut expression in two recent phases in the evolution of Western 426 society (e.g., Parsons 1971: 86-121). He pointed, on the one hand, to the industrial 427 revolution of the eighteenth century with its emphasis on economic production, 428 instead of on the extraction of natural resources. On the other hand, the interest in 429 scientific knowledge, which became dominant in the second part of the twentieth 430 century, also expressed this value pattern. For Parsons, both the industrial and the 431 "postindustrial" types of society were exponents of a similar value pattern. Both the 432 industrial revolution and the educational revolution (i.e., the realization of mass 433 higher education) were manifestations of adaptive value patterns. The adaptive 434 stress that gave primacy to economic production also legitimized the concern with 435 the "cognitive complex" within modern society, i.e., the development and dissem- 436 ination of scientific knowledge. Both the forms of economic production and 437 knowledge acquisition were (or had) to be subsumed under a more generally 438 
conceived valuation of enhanced adaptive capacity in the contemporary society. In this regard, the analyses and reflections presented in The American University (Parsons and Platt 1973) can be seen to provide a complement to those first presented in Economy and Society (Parsons and Smelser 1956). ${ }^{4}$

In The American University, Parsons' theoretical focus is on what he called the value component of cognitive rationality: "the term 'cognitive' has a cultural reference whereas that of the term 'rational' is primarily social. Cognitive rationality is a value-pattern linking the cultural and the social levels which are not reducible to one another" (Parsons and Platt 1973: 38). Parsons, moreover, stressed the distinction and the affinity between the value patterns of economic and cognitive rationality in the American society of his time. "As opportunities opened up, the normative pressure of the value-system worked to encourage concern with rationality, not only in the economic direction but also in the cognitive and in certain others. The link lies in the adaptive function... The same value-system that favored economic development also favored cognitive development" (Parsons and Platt 1973: 44-45, orig. emphasis). Interestingly, "cognitive rationality" is now also dealt with as one particular mode or type of rationality. Parsons saw the current primacy of scientific knowledge and cognitive rationality as constituting one phase in the process of rationalization. It was a consequence of the way in which the modern, American society itself had become organized.

Against this background, The American University concentrated on "the modern university, especially in its American version," while the university was seen as "the current culmination of the educational revolution" and "the lead component of an extensive process of change permeating modern society at many levels" (Parsons and Platt 1973: 3). Following Parsons, the "educational revolution," i.e., the swift expansion of the system of higher education in the course of the twentieth century, facilitated the implementation and actualization of the value pattern of cognitive rationality. By enhancing the capacity for rational action, the rapid expansion of the academic system had been instrumental in "upgrading" the adaptive potential of modern societies, such as the American type of society. In the course of the twentieth century, he argued that "higher education, including the research complex, had become the most critical single feature of the developing structure of modern societies" (1973: vi). Elsewhere Parsons and Platt likewise argued: "There is a more or less unconscious sense of affinity with cognitive rationality among most of those who share the instrumentally activist orientation; this sense of affinity becomes more positive and more explicit in the increasingly large proportion of the population which has itself received a higher education" (1968: 507).

\footnotetext{
${ }^{4}$ For this reason, Smelser originally also was asked to coauthor The American University. However, differences of opinion about various lines of analysis imperiled the renewed collaboration. Eventually, Smelser wrote a critical epilogue to the monograph. For a detailed analysis of the making of The American University, based upon archival material, see Vanderstraeten (2015). For an illuminative view on Parsons' account of the functions of culture in social action, see Staubmann (2005).
} 
In the aforementioned autobiographical essay, Parsons spoke with reference to 477 Freud, of his return to the problem of rationality in The American University as the 478 "return of the repressed" (1970, 1977: 36). Reading between the lines of his 479 autobiographical essay, one may gain the impression that the book or at least its 480 second chapter, which delineates the problem of cognitive rationality, constituted 481 the chapter that he did not write some three decades earlier for the Schumpeter- 482 Parsons Seminar on Rationality. In The American University, Parsons clearly opted 483 for a constructivist approach, which focused on the consequences of the expansion 484 of the cognitive complex at the level of the total society. He focused on the ways in 485 which cognitive rationality penetrated and transformed other subsystems of society. 486 But despite the prominence that, in his view, the cognitive complex had gained in 487 modern society, Parsons also relativized its impact. Its primacy was historically 488 contingent, because science was only one of many subsystems in society-which 489 only at the moment occupied a relatively high position in the hierarchy of functions 490 on behalf of the total society.

Elsewhere, Parsons also stated that the culturally sanctioned primacy of active 492 adaptation in modern societies served to legitimate the pursuit of empirical knowl- 493 edge, which could be used to master the world, and thus to increase rationality and 494 further rationalization. In his own words, "indeed a society, the central values of 495 which are 'activistic', is almost driven to the feeling that ... the pursuit of 496 knowledge is essential to its prosperity and development as a society. Broadly 497 speaking I feel that this activistic component of values has indeed been prominent 498 in the whole of modern society, perhaps particularly the United States, and that 499 these values have given a strong impetus to welcome rationalization in this broad 500 sense and indeed actively to promote it" (1970: 612). On the basis of the workings 501 of this overarching value pattern, he believed that the coherence of the heteroge- 502 neous rationalities of the different societal subsystems could be guaranteed. The 503 basic value pattern of instrumental activism ensured the unity of the different 504 rationalities in society as a system.

In a number of ways, much of his late work also departed from the idea that the 506 primacy given to adaptive functions accelerated structural differentiation processes 507 within modern societies. As a consequence, he believed, social systems were 508 increasingly faced with problems of integration. Social differentiation would espe- 509 cially lead to strains and tensions within the "societal community" (see 510 Vanderstraeten 2013). For Parsons, rationalization thus particularly had an effect 511 on systems specializing in the functions of either adaptation (A) or integration (I). 512 Against this background, he discussed in his later, and partly posthumously 513 published, writings several historical "crises" that, alternately, put emphasis on 514 either of these functional requirements. He paid ample attention to the industrial 515 (A) and the democratic (I) revolution in the "long" nineteenth century but also to 516 the educational (A) and the expressive (I) revolution of the twentieth century (e.g., 517 Parsons 2007).

In The American University, Parsons and Platt explicitly maintained that "the net 519 impact of the educational revolution is constructive" (1973: 3). While the student 520 revolt of the 1960s and early 1970s put emphasis on the nonrational and expressive 521 
aspects of the human condition, Parsons did not believe that a fundamental distrust of cognitive culture was developing at that time. Parsons and Platt discussed the disturbances as consequences of the swift expansion of the university system but also thought of the "permanent institutionalization of the extreme positions prominent in the acute phase of disturbance" (1973:345) was something very unlikely to occur. In the long run, "continuity and change" had to go hand in hand in modern society. As a consequence of his untimely death, however, most of these reflections have remained incomplete.

\section{Conclusion}

Parsons famously characterized himself as an "incurable theorist." In the course of his long and productive career, he indeed never stopped reconsidering and revisiting basic theoretical concepts. On the foregoing pages, it was not possible to deal in every necessary detail with the lines of continuity and change in his understanding of rationality. But, at the risk of oversimplifying the nuances of his analytic approach, it can be maintained that Parsons' understanding of rationality shifted from an orientation to the individual economic actor to one that emphasized the complex structure of the value system at the social level (see also Staubmann 2015). He thereby moved from a "natural" or universalist conception of rationality to a constructivist one, which particularly put emphasis on the impact of the "cognitive complex," i.e., the systems of science and university education, both in and on modern society.

In the years 1939 and 1940, when Schumpeter and Parsons co-organized the Seminar on Rationality in the Social Sciences at Harvard University, this transition had not yet taken place. Parsons seemed in these years no longer satisfied with the concept of rationality, which he had used and developed in his early writings, including The Structure of Social Action, and which had also attracted Schumpeter's interest. In his own autobiographical statements, Parsons referred to institutional changes, viz., his transfer from the Economics to the Sociology Department at Harvard University, to account for his reticence with regard to the Seminar on Rationality. On the foregoing pages, I have suggested that new intellectual challenges also triggered his reconsideration of his relation to economics and economic theory. These intellectual challenges continued after Parsons' formal transfer to the Sociology Department and later the interdisciplinary Department of Social Relations. I have here tried to sketch why Parsons had difficulty participating in a project that (still) took its point of departure from an economic concept of rationality. Parsons' decision "to let it die" can best be understood against the background of these shifting interests and concerns.

In the 1950s and 1960s, Parsons' micro-sociological account of rationality was gradually replaced by a macro-sociological one, in which attention was focused on the social conditions that allowed for the institutionalization of particular value orientations. In his later work, Parsons dealt with rationality as part of the shared 
system of social values, as the institutionalization of particular social norms and 563 expectations - and no longer as the mode of implementation of those values. He 564 also put stress on the functional affinity between rationality and adaptation. Hence, 565 he emphasized connections between rationality and social subsystems specialized 566 in "adaptive upgrading." It is perhaps too strong to contend that the second chapter 567 of The American University constitutes the chapter Parsons did not complete about 568 three decades earlier. But, in his own self-understanding, this analysis of the rise 569 and social impact of cognitive rationality seems to come closest to the largely 570 unwritten chapter of 1940.

\section{References}

Allen, Robert Loring. 1991. Opening Doors: The Life and Work of Joseph Schumpeter, Vol. 2: 573 America. New Brunswick: Transaction Publishers.

Baum, Rainer C. 1976. Introduction to Part IV. In Explorations in General Theory in the Social 575 Sciences: Essays in Honor of Talcott Parsons, ed. Jan J. Loubser, Rainer C. Baum, Andrew 576 Effrat, and Victor M. Lidz, vol. 2, 448-469. New York: Free Press.

Hein, Stephan. 2009. Konturen des Rationalen: Zu einem Grundmotiv im Theoriewerk von Talcott 578 Parsons. Konstanz: UVK.

. 1935. The Place of Ultimate Values in Sociological Theory. International Journal of 583 Ethics 45 (3): 282-316.

. 1937. Remarks on Education and the Professions. International Journal of Ethics 47 (3): 585 $365-369$.

1968b. Utilitarianism: Sociological thought. In International Encyclopedia of the Social 592

1968c. Professions. In International Encyclopedia of the Social Sciences, ed. David 594

L. Sills, vol. 12, 536-547. New York: Macmillan.

1973. Nature and extent of value systems of modern society. In New Problems of 601

Advanced Societies, 137-142. Tokyo: Japan Economic Research Institute. 602

. 1977. Social Systems and the Evolution of Action Theory. New York: Free Press. 603

. 1991. A tentative outline of American values. In Talcott Parsons: Theorist of Modernity, 604

ed. Roland Robertson and Bryan S. Turner, 37-65. London: Sage. 605 2006. A Seminar with Talcott Parsons at Brown University. American Journal of 606 
. 2010. Actor, situation and normative pattern. In Actor, Situation and Normative Pattern: An Essay in the Theory of Social Action, ed. Victor Lidz and Helmut Staubmann, 31-167. Wien: LIT Verlag.

Parsons, Talcott, Robert F. Bales, and Edward A. Shils. 1953. Working Papers in the Theory of Action. New York: Free Press.

Parsons, Talcott, and Gerald M. Platt. 1968. Considerations on the American Academic System. Minerva 6 (4): 497-523.

. 1973. The American University. Cambridge: Harvard University Press.

Parsons, Talcott, and Edward A. Shils. 1951. Categories of the orientation and organization of action. In Toward a General Theory of Action, ed. Talcott Parsons and Edward A. Shils, 53-109. Cambridge: Harvard University Press.

Parsons, Talcott, and Neil J. Smelser. 1956. Economy and Society. London: Routledge \& Kegan Paul.

Schumpeter, Joseph A. 1991. In The Economics and Sociology of Capitalism, ed. Richard Swedberg. Princeton: Princeton University Press.

Smelser, Neil J. 1981. On Collaborating with Talcott Parsons: Some Intellectual and Personal Notes. Sociological Inquiry 51 (3-4): 143-153.

Staubmann, Helmut. 2005. Culture as a subsystem of action: Autonomous and heteronomous functions. In After Parsons: A Theory of Social Action for the Twenty-First Century, ed. René Fox, Victor M. Lidz, and Harold Bershady, 169-178. New York: Russel Sage.

. 2015. Rise and Decline of Functionalism and Current Problems of Methodology in the Social Sciences. Sartoniana 28: 145-159.

Stichweh, Rudolf. 1980. Rationalität bei Parsons. Zeitschrift für Soziologie 9 (1): 54-78.

Swedberg, Richard. 2015. Schumpeter and Talcott Parsons. Journal of Evolutionary Economics 25 (1): 215-222.

Turner, Jonathan H. 1988. A Theory of Social Interaction. Stanford: Stanford University Press. Vanderstraeten, Raf. 2013. Talcott Parsons and the Enigma of Secularization. European Journal of Social Theory 16 (1): 69-84.

- 2015. The Making of Parsons's 'The American University'. Minerva 53 (4): 307-325.

Weber, Max. 1988. Gesammelte Aufsätze zur Religionssoziologie I. Tübingen: Mohr. 


\section{Author Queries}

Chapter No.: 15 427253_1_En

\begin{tabular}{|c|c|c|}
\hline Query Refs. & Details Required & Author's response \\
\hline AU1 & $\begin{array}{l}\text { Ref. "Parsons } 1939 \text { " is cited in text } \\
\text { but not provided in the reference list. } \\
\text { Please provide details in the list or } \\
\text { delete the citation from the text. }\end{array}$ & \\
\hline AU2 & $\begin{array}{l}\text { Please check if edit to sentence } \\
\text { starting "This project is..." is okay. }\end{array}$ & \\
\hline AU3 & $\begin{array}{l}\text { The reference citation "year/year" } \\
\text { has been changed as per the } \\
\text { springer syle. }\end{array}$ & \\
\hline AU4 & $\begin{array}{l}\text { Ref. "Weber } 1920 \text { " is cited in text } \\
\text { but not provided in the reference list. } \\
\text { Please provide details in the list or } \\
\text { delete the citation from the text. }\end{array}$ & \\
\hline AU5 & $\begin{array}{l}\text { Ref. "Luhmann } 1968 \text { " is cited in text } \\
\text { but not provided in the reference list. } \\
\text { Please provide details in the list or } \\
\text { delete the citation from the text. }\end{array}$ & \\
\hline AU6 & $\begin{array}{l}\text { Reference "Parsons, 1966" was not } \\
\text { cited anywhere in the text. Please } \\
\text { provide a citation. }\end{array}$ & \\
\hline
\end{tabular}

